Historic, Archive Document

Do not assume content reflects current scientific knowledge, policies, or practices. 



\section{GLADIOLUS BULBS Quantity and quality at prices that don't hurt}

Sizes 3-4 to inch diameter. Bloom perfectly first year.

Not less than 25 of a kind at these prices nor any order for less than $\$ 1$. worth, except when combined with other bulb orders.

*AMERICA-giant lavender-pink,

Bulbs Bulblets per 25 per 1000

ALBANIA - Best giant white, pure ........ 1.50 .50 *ARIZONA-Good tall early rose............ ALICE TIPLADY - Famous orange prim.

*BORDEAUX-Early large wine,

1.00

.75

CRACKER ACK DIENER HYBRIDS--California giants, . . ...... FRANCES KING-Giant scarlet, tall ......... GLORY OF KENNERMERLAND-Giant rose, . *HALI.EY-Giant early salmon, ............ IDA VAN-Large salmon red, .35 .35

.50

.35

.75

.30

.35

*INTENSITY - Scarlet, marbled white, . . . . . . *INDEPENDENCE-Begonia rose, tall, KING PHILLIP-Handsome large red, ......... LE MARECHAL FOCH-Giant light pink .... MRS. WATT-American Beauty Rose, ....... *MRS. FRANK PENDLETON-Famous pink,....

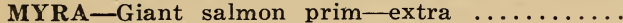

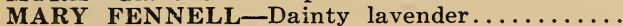

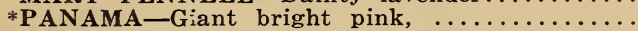
*PRINCE OF WALES-Purest salmon, .......

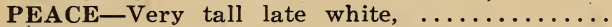
*WILBRINK-Fine early light pink, ......... RED EMPEROR-King of the deep scarlets .... *YELLOW HAMMER-Almost pure yellow, ..... *CHOICE MIXED-Above and others, ..........

*Can furnish bublets of these at 3 times the thousand rate for one quart. Bublets per $100,1-5$ the rate per thousand.

\section{PAUL L. WARD, Plantsman}




\section{Special Gladiolus Offers For Flower Lovers}

10 each 10 kind, $1-2$ inch size, $\ldots \ldots \ldots \ldots \ldots \ldots \ldots \ldots . .90$

10 each 10 kinds, $3-4$ inch size, $\ldots \ldots \ldots \ldots \ldots \ldots \ldots \ldots . .50$

10 each 10 kinds, $11-4$ inch size, ................. 3.00

Most of the first item and all of the two last bloom first year.

\section{The following fine mixtures at bargain rates}

75 Choice large flowering $3-4$ to 1 inch in size,

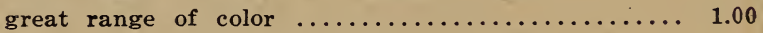

10050 per cent. above mixture and 50 per cent.

primulinus, $\ldots \ldots \ldots \ldots \ldots \ldots \ldots \ldots \ldots \ldots \ldots \ldots . \ldots \ldots . . \ldots \ldots$

200 of first mixture, but in size $1-2$ to $3-4$ inch $\ldots \ldots \ldots 1.00$

50 large, first size bulbs mixed $\ldots \ldots \ldots \ldots \ldots \ldots \ldots \ldots \ldots$

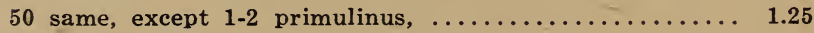

\section{Brand New Variety Offers}

25 All Different, large flowering $3-4$ to 1 inch, ........75 (Contains many expensive varieties)

Fancy Sorts-One dozen all different, 1 1-4 inch, .....\$2.00 (This is made up of $20 \mathrm{c}$ and $25 \mathrm{c}$ kinds.)

\section{PAUL L. WARD, Plantsman}

